and, indeed, was more proud of this title than any other. In almost every branch of the analysis of food and drugs he has left his mark. As a witness he was superb; in the box he told a plain unvarnished tale in perfect English (although he never lost his accent), and carried conviction. Before parliamentary committees also, he placed his wide knowledge, and there is no doubt but that his evidence had a distinct influence on legislation, and his expert advice was welcomed in many quarters.

During the War, Hehner devoted himself wholeheartedly to the country of his adoption; his expert knowledge of glycerin technology was placed at the service of the country without remuneration, and he served on various committees where his knowledge was invaluable. His reward was that some pettifogging local authorities removed him from his public appointments because of his German origin; how little they knew the man, who had given them such good service. Hehner was greatly hurt by this, and it affected his health; partly on this account, but chiefly to escape what he felt was an anomalous position, he went to South Africa in I92I, and though he came back, he paid another temporary visit, and died there on September 9 of a tropical fever.

Full of energy, kind-hearted and generous, especially to young men, a keen critic, and a strong fighter, but always in a fair and just manner, a firm staunch friend, a widely read philosopher, a genial companion, he had that strong personality and marvellous intuitive brain that marks a leader.

H. D. R.

\section{Mr. J. Britten.}

THE sudden death of James Britten, fellow of the Linnean Society and for nearly forty-five years editor of the Journal of Botany, British and Foreign, occurred at Brentford on October 8 . He was born at Chelsea on May 3, I846, and became attracted to the study of plants from an early age. His earliest printed paper known to the writer is in the Journal of Botany, in the first volume of which, issued in 1863 , is a short paper on "Rare and Eyotic Plants at Kew Bridge." In 1865 he removed to High Wycombe, and the four years spent in that town gave him further opportunities for studying field botany.

Short papers came from Britten's pen quickly ; then in 1869 he was appointed a junior assistant in the herbarium of the Royal Botanic Gardens, Kew. Two years later he was transferred to the Department of Botany, British Museum, then housed at Bloomsbury. In $x 879$ the senior assistant, Henry Trimen, proceeded to Ceylon, succeeding Thwaites at the botanical garden of Peradeniya, and Britten took his place as editor of the Journal of Botany, which he occupied until his death last week.

Britten's independent works were a quarto on "European Ferns," in I881-82, a reprint of William Turner's "The Names of Herbes in Greke, Latin, Englishe, Duche and Frenche, I 548," with the identification of the plants, in I88I ; a list of farming words, extracted from Wm. Ellis, in I880; and the determinations of Banks's plants issued in folio by the Trustees of the British Museum, in r900-I905. With
Robert Holland he brought out "A Dictionary of English Plant Names," r878-84; and with Prof. Boulger "A Biographical Index of British and Irish Botanists," I893, with three subsequent Supplements to I908; a second edition is understood to be ready for press.

Britten, however, was better known as a keen debater and critic, in his own journal, and the number of his essays, long or short, is great. He was quick to detect the weak side of an adversary, and unsparing in attack. For many years he took an active part in the work of the Catholic Truth Society, in recognition of which he was made a knight of the order of Saint Gregory in $\mathrm{I} 897$, by Pope Leo XIII., and knight commander (K.C.S.G.), con placca, in I9I7. B. D. J.

\section{Prof. H. Kraemer.}

The death on September 9 of Prof. H. Kraemer at Detroit, which has robbed pharmacognosy of one of its most brilliant exponents, will be much deplored by his colleagues not only in the United States but also throughout the scientific world generally. Henry Kraemer was born on July 22, I868, and studied at the Philadelphia College of Pharmacy while still an apprentice in a pharmacy in that city. In 1889 he graduated in pharmacy there and afterwards took the degree of Bachelor of Philosophy in the School of Mines of Columbia University. He was then appointed professor of botany and pharmacognosy in the School of Pharmacy of the Northwestern University. $\mathrm{He}$ studied for an additional year in Marburg, chiefly under the late Prof. Arthur Meyer, and obtained the degree of Ph.D. Soon after his return to America he was called to fill the chair of botany and pharmacognosy in the Philadelphia College of Pharmacy, a position which he continued to hold until $x 917$, when he was transferred to a similar position in the University of Wisconsin.

From 1899 to 1917 Prof. Kraemer was the editor of the American Journal of Pharmacy. During this time he exhibited indefatigable industry, not only in his capacity as editor but also as research worker in the laboratory, mainly in the fields of botany and pharmacognosy. He also took an active part in the revision of the United States Pharmacopœia as chairman of the sub-committee on botany and pharmacognosy. In Great Britain he was best known by his "Scientific and Applied Pharmacognosy " and "Applied and Economic Botany," his ability receiving recognition by his appointment as honorary member of the British Pharmaceutical Conference. Prof. Kraemer exercised a widespread influence, particularly in America, by his industry and by the stimulus he imparted to others by the example he set. He was an independent thinker and gave fearless expression to his thoughts, a trait which made correspondence with him a sincere pleasure. His loss will be keenly felt.

WE regret to announce the following deaths :

Lord Abercromby of Aboukirand Tullibody, formerly president of the Society of Antiquaries of Scotland and honorary member of the Finno-Ougrian Society of Helsingfors and of the Finnish Archæological Society, on October 7 , aged eighty-three.

Dr. W. B. Hemsley, F.R.S., formerly Keeper of the Herbarium, Royal Botanic Gardens, Kew, on October 7 , aged eighty.

$$
\text { NO. } 2868 \text {, vOL. I I } 4 \text { ] }
$$

